\title{
PERANAN ORANG TUA TERHADAP PERILAKU ANAK SEBAGAI PEMIRSA TELEVISI DIRUMAH
}

\author{
Oleh: \\ Putri Wardatul Asriyah, Budi M. Taftazani \& dan Meilany Budiarti S. \\ Email: \\ Asriyah2@gmail.com
}

\begin{abstract}
ABSTRAK
Televisi merupakan hiburan masif yang dimiliki mayoritas keluarga di Indonesia. sudah seperti suatu kelaziman disetiap rumah pasti memiliki minimal satu buat televisi. Mengapa televisi menjadi hiburan yang sangat diminati oleh sebagian besar keluarga di Indonesia? tentunya karena kemudahan yang ditawarkan. Hanya dengan membeli satu buah televisi dengan harga yang bervariatif baik itu murah ataupun mahal, televisi dapat mencukupi kebutuhan hiburan dirumah untuk satu keluarga sekaligus. Televisi dianggap sebagai kotak ajaib karena sdari kotak itulah kita dapat menerima banyak informasi.
\end{abstract}

Yang menjadi pertanyaan adalah: apakah informasi tersebut tepat untuk dinikmati oleh anggota keluarga yang terdiri dari ayah, ibu dan anak? Disiniliah peneliti merasa perlu mengadakan penelitian karena melihat banyak fakta dilapangan yang menunjukan bahwa banyak anak-anak terkena dampak buruk dari televisi tersebut. Seperti kita ketahui banyak informasi yang diberikan televisi memberikan kekerasan secara visual terhadap anak. Adanya tayangan mengenai bullying, kekerasan rumah tangga, perceraian dan lain-lain yang tidak child friendly.

Disini peneliti ingin melihat apakah peranan pengawasan dari orang tua terhadap anak sebagai pemirsa televisi memberikan pengaruh yang besar terhadap perubahan perilaku anak.

Keyword : Tayangan Televisi, Perilaku Anak, Peranan Orangtua

\section{ABSTRACT}

Television is an entertainment massive majority owned by the family in Indonesia. already as a norm in every house must have at least one for television. Why become entertainment television that is in demand by most families in Indonesia? of course, because of the convenience offered. Only by buying a single television with prices varying either cheap or expensive, television can meet the needs of home entertainment for the family as well. Television is regarded as a magic box because sdari box that we can receive a lot of information.

The question is whether the information is appropriate to be enjoyed by members of the family consisting of father, mother and child? Disiniliah researchers feel the need to conduct research in the field because they see a lot of facts that show that many children were badly affected by the television. As we know a lot of information given television provides visual violence against children. Their impressions about bullying, domestic violence, divorce and others that are not child friendly. 
Here, the researchers wanted to see whether the oversight role of parent to child as television viewers have a considerable influence on children's behavior changes.

Keyword: Watch TV, Child Behavior, Role of Parents

\section{PENDAHULUAN}

Keluarga merupakan unit dasar terkecil dimana anggotanya terdiri dari ayah, ibu dan anak. Ayah dan ibu merupakan orang tua yang meiliki tanggung jawab untuk mengasuh dan memberikan kasih sayang untuk anak. Selain itu anak sebagai pemegang garis keturunan bertanggung jawab untuk menjadi pribadi yang dapat dibanggakan oleh orang tuanya. Agar seorang anak dapat menjadi seseorang yang dibanggakan oleh orang tuanya, orang tua harus memiliki peranan yang dapat dijadikan pedoman berprilaku oleh anak. Peranan orang tua harus dapat memenuhi kebutuhan psikis dan fisik seorang anak. Apabila dilihat dari perspektif pekerja sosial, interaksi yang baik antara orang tua dan anak dapat menciptakan hubungan kondusif yang memberikan pengaruh besar terhadap perkembangan anaknya. Interaksi tersebut dapat dibangun dengan melakukan kegiatan yang bersifat hiburan bersama-sama.Lazimnya hiburan yang mudah didapat oleh keluarga dirumah adalah televisi. Hampir semua orang di Indonesia memiliki perangkat televisi dirumahnya. Alasan mengapa televisi dijadikan hiburan semua orang adalah karena televisi sangatlah mudah unutk diakses.

Televisi merupakan salah satu hiburan masa kini yang dapat kita nikmati dengan sangat mudah karena dapat diakses dirumah kita sendiri. Menonton televisi sering kali dijadikan sebagai waktu keluarga untuk berkumpul menikmati acara televisi yang disukainya.

Tetapi sering kali acara - acara yang ditawarkan oleh pihak stasiun televisi tidak selalu aman untuk dinikmati oleh keluarga. Banyak acara televisi yang mempertontonkan kekerasan secara fisik dan juga perilaku perilaku remaja yang menyimpang.

Berikut merupakan salah satu kasus yang sempat ramai dibicarakan yang dilansir dari blog Editorial Media Massa Indonesia "korban tiru-tiru adegan gulat bebas di televisi yang dikenal dengan acara smack downmulai bermunculan setelah tewasnya Reza Ikhsan Fadilah (9) siswa kelas III SDN Cingcin I Katapang, Kabupaten Bandung, Jawa Barat, pertengahan November lalu. Reza meninggal setelah sempat sakit seusai bermain gulat bebas bersama tiga temannya. Sejumlah saksi menuturkan, Reza konon dipelintir kedua tangannya ke belakang dan kemudian ditindih tiga temannya. Permainan ini dilakukan meniru-niru adegan yang mereka lihat dalam tayangan televisi.Korban lainnya ialah seorang siswa SD di Yogyakarta yang harus dirawat di rumah sakit karena gegar otak ringan setelah jatuh di-smack down kawannya."

Dapat dilihat dampak buruk televisi bahkan bisa sampai pada tahap merenggut nyawa anak. Pihak KPI sendiri yang bertanggung jawab dalam menyensor tayangan - tayangan yang dikeluarkan oleh pihak televisi telah mengeluarkan pedoman menonton yang seharusnya dijadikan acuan oleh orang tua untuk mengawasi anggota keluarganya dalam menonton televisi.

Anak menurut UU RI No. 4 tahun 1979 adalah seseorang yang belum mencapai usia 21 tahun dan belum pernah menikah. Batas 21 tahun ditentukan karena berdasarkan pertimbangan usaha kesejahteraan sosial, kematangan pribadi, dan kematangan mental seorang anak dicapai pada usia tersebut.

Dalam undang-undang diatas dijelaskan bahwa anak belum mencapai kematangan mental sebelum menginjak usia 21 tahun oleh karena itu bimbingan orang tua merupakan hal yang sangat perlu diperhatikan agar anak tidak mengalami kesalahan pembinaan. Apabila anak terus menerus menerimaasupan yang tidak baik dari televisi hal ini akan berdampak pada psikologis anak bahkan anak pun dapat meniru apa yang mereka lihat dari televisi. 
Dilihat dari sisi psikologi hal ini pun dapat dikatakan merupakan kekerasan dalam bentuk visual untuk anak.

Berdasarakan latar belakang diatas maka permasalahan yang muncul apabila anak dibiarkan menonton televisi tanpa bimbingan orang tua adalah :

- Seberapa besar pengaruh peranan orang tua terhadap perilaku anak?

- Apa saja pengaruh televisi terhadap perilaku anak?

- Peranan apa saja yang harus diberikan oran tua dirumah?

- Bagaimana ciri-ciri anak yang telah terpengaruh oleh televisi?

\section{HASIL DAN PEMBAHASAN}

Keluarga merupakan bagian masyarakat yang fundamental bagi kehidupan pembentukan kepribadian anak manusia. Hal ini diungkapkan Syarief Muhidin (1981:52) yang mengemukakan bahwa : "Tidak ada satupun lembaga kemasyarakatan yang lebih efektif di dalam membentuk keperibadian anak selain keluarga. Keluarga tidak hanya membentuk anak secara fisik tetapi juga berpengaruh secara psikologis".

Pendapat diatas dapat dimungkinkan karena keluarga merupakan lingkungan pertam dan utama bagi seorang anak manusia, di dalam keluarga seorang anak dibesarkan, mempelajari cara-cara pergaulan yang akan dikembangkannya kelak di lingkungan kehidupan sosial yang ada di luar keluarga. Dengan perkataan lain di dalam keluarga seorang anak dapat memenuhi kebutuhankebutuhannya, baik kebutuhan fisik, psikis maupun sosial, sehingga mereka dapat tumbuh dan berkembang dengan baik.

Disamping itu pula seorang anak memperoleh pendidikan yang berkenaan dengan nilai-nilai maupun norma-norma yang ada dan berlaku di masyarakat ataupun dalam keluarganya sendiri serta cara-cara untuk menyesuaikan diri dengan lingkungannya.
Sedangkan istilah keluarga itu sendiri memiliki beraneka ragam pngertian, salh satunya diungkapkan oleh Paul B Houton dan Chester L Hunt (1987:267) adalah sebagai berikut :

- Suatu kelompok yang mempunyai nenek moyang yang sama

- Suatu kelompok kekerabatan yang disatukan oleh darah atau perkawinan

- Pasangan perkawinan dengan atau tanpa anak

- Pasangan tanpa nikah yang mempunyai anak

- Satu orang dengan beberapa anak.

Pada saat seorang manusia lahir ke dunia, interaksi pertama yang mereka lakukan adalah kepada kedua orang yang bertanggung jawab atas lahirnya ia ke dunia. Kedua orang tersebut adalah orang tua. Menurut Thamrin dan Nurhadjun Nastion mengemukakan bahwa:

"Orang tua adalah setiap orang yang bertanggung jawab dalam satu keluarga atau rumah tangga yang dalam penghidupan seharihari lazim disebut ibu/bapak, sedangkan anakanak atau semua yang berada dibawah pengawasan maupun asuhan dan bimbingan orang disebut keluarga; adalah unit dasar masyarakat yang merupakan bentuk kelompok yang bersatu oleh ikatan perkawinan, darah, atau, adopsi, serta terikat pada hubungan biologis, sosial, ekonomi keluarga."

Orang tua selaku orang yang dituakan oleh anak dan merupakan pihak yang memiliki tanggung jawab untuk memberikan pengawasan dan kasih sayang memiliki peranan-peranan yang harus dipenuhi untuk mencapai kesejahteraan seorang anak. Menurut Alfred Kadushin peranan orang tua terhadap anak adalah sebagai berikut:

- $\quad$ Orang tua diharapkan untuk memberikan penghasilan yang dapat memenuhi kebutuhan-kebutuhan anak terhadap makanan, pakaian, tempat berteduh, pendidikan, kesehatan, kegiatan sosial dan rekreasi.

- Orang tua diharapkan untuk dapat memberikan kebutuhan emosional bagi 
anak yaitu pemberian cinta, rasa aman, kasih sayang, dukungan terhadap kebutuhan emosional yaitu terhadap perkembangan emosi yang sehat.

- Orang tua diharapkan untuk dapat memberikan rangsangan yang penting untuk kecerdasan yang normal, perkembangan sosial dan spiritual dimana keluarga mengaggap bahwa hal ini penting. Ini berarti orang tua harus mencarikan sekolah yang sesuai bagi anak dan anak dapat terdorong untuk bermain juga mencarikan tempat yang cocok dimana anak dapt terangsang atau terdorong untuk memperoleh pelayanan yang lebih baik.

- $\quad$ Orang tua harus membantu sosialisasi anak. Sosialisasi adalah suatu proses dari pengaruh yang membawa kepada suatu pergaulan yang baru pada kelompok sosial dan mendidik mereka keapda tingkah laku yang biasa atau yang diterima oleh kelompok

- $\quad$ Orang tua harus melindungi anak dari gangguan fisik, emosional dan sosial.

- Orang tua harus mendisiplinkan anak dan menjaga dia dari pola pertumbuhan tingkah laku, perasaan atau sikap yang tidak disetujui oleh kelompoknya.

- Orang tua harus menampilkan diri bahwa dia adalah meruapakan contoh atau model dari tokoh identifikasi lawan jenis misalnya ayah adalah contoh dari kejantanan dan ibu merupakan contoh dari kewanitaan.

- $\quad$ Orang tua harus tetap menajga hubungan antara anggota keluarga agar tetap stabil, memberikan dasar-dasar yang memuaskan dan diusahakan untuk mempertemukan kebutuhan-kebutuhan dari seluruh anggota keluarga. Orang tua harus membantu memecahkan pertengkaran yang tidak menyenangkan dan memuaskan dan mempertemukan kebutuhan emsosional dengan cara menerima tindakan aksih sayang.
- $\quad$ Orang tua harus menyediakan suatu tempat tinggal yang tetap dan jga menentukan keanggotaan dia didalam kelompok sosial yang lebih besar, serta menyediakan tempat yang bersih atau baik untuknya didalam masyarakat. Dengan demikian anak mengetahui siapa dia yang sebenarnya dan terutama anak dapat mencapai suatu gambaran diri yang lebih stabil.

Selain itu peran orang tua adalah

1. Orang tua harus menjadi panutan, karena anak akan melihat dan menyerap pola perilaku dan nilai-nilai yang ditampilkan orang tua.

2. Orang tua menjadi teman diskusi dan sumber informasi bagi anak tentang segala hal.

3. Orang tua perlu mengembangkan tradisi kekeluargaan dan nilai-nilai agama, dengan mengerjakan pekerjaan rumah bersama-sama dan melaksanakan ibadah bersama.

4. Orang tua menggali potensi anak untuk dikembangkan melalui berbagai macam kegiatan positif, sehingga dapat menumbuhkan rasa percaya diri anak.

5. Orang tua menjadi pembimbing bagi anak dalam membantu mengatasi berbagai masalahyang dihadapi oleh anak.

6. Orang tua perlu mengetahui kegiatan anak, hal ini untuk menunjukkan bahwa orang tua punya perhatian khusus pada anak.

7. Orang tua perlu mengenal teman-teman anaknya dan bergabung untuk mengobrol bersama mereka.

Dalam pandangan pekerjaan sosial, masalah perilaku anak yang dipengaruhi dari kegiatan menonton televisi dilihat dari interaksi orang tua dengan anaknya. Apabila pada suatu keluarga orang tua dan anak memiliki interaksi yang baik dalam artian orang tua menjalankan peranannya maka perilaku anak yang kurang 
baik dapat dihindari. Keadaan ini juga akan berlaku sebaliknya. Selain itu orang tua dan peranannya sangat mempengaruhi dan menentukan terhadap perkembangan fisik, psikis, akademik dan sosial anak. Oleh karena itu orang tua sebagai unit penopang dari suatu keluarga haruslah memiliki kemampuan interaksi yang baik dengan anak.

Anak merupakan siapa saja yang belum berusia 18 tahun. Pada keluarga anak adalah pemegang garis keturunan orang tuanya. Menurut WHO batasan usia anak adalah 0-19 tahun. Dalam penelitian ini usia anak yang akan diteliti adalah 6-12 tahun. Karena pada usia ini anak akan berada pada tahap menyulitkan orang tua sehingga lebih menarik untuk diteliti.

Permulaan awal masa anak akhir ditandai dengan masuknya anak ke sekolah formal di SD kelas satu. Masuk SD kelas 1 merupakan peristiwa penting bagi kehidupan setiap anak, sehingga dapat mengakibatkan perubahan dalam sikap dan perilakunya. Sementara anak menyesuaikan diri dengan tuntutan dan harapan sosial di sekolah, kebanyakan anak berada dalam keadaan tidak seimbang (disequilibrium).

Karakteristik atau ciri-ciri periode masa anak akhir, sama halnya dengan ciri-ciri periode masa anak awal denganmemperhatikan sebutan atau label yang digunakan orang tua, pendidik, maupun psikolog perkembangan anak. Orang tua menyebut masa anak akhir sebagai usia yang menyulitkan karena anak pada masa ini anak lebih banyak dipengaruhi oleh teman-teman sebaya daripada oleh orang tuanya sehingga sulit bahkan tidak mau lagi menuruti perintah orang tuanya. Kebanyakan anak pada masa ini juga kurang memperhatikan dan tidak bertanggung jawab terhadap pakaian dan benda-benda miliknya, sehingga orang tua menyebutnya usia tidak rapi. Anak tidak terlalu memperdulikan penampilannya. Mereka cenderung ceroboh, semaunya, dan tidak rapi dalam memelihara kamar dan barang-barangnya. Pada masa ini, anak juga sering kelihatan saling mengejek dan bertengkar dengan saudara-saudaranya sehingga orang tua menyebutnya sebagai usia bertengkar.

Para pendidik memberi sebutan anak usia sekolah dasar, karena pada rentang usia ini (612 tahun) anak bersekolah di sekolah dasar. Di sekolah dasar, anak diharapkan memperoleh dasar-dasar pengetahuan dan keterampilan yang dianggap penting untuk keberhasilan melanjutkan studi dan penyesuaian diri dalam kehidupannya kelak. Para pendidik juga memandang periode ini sebagai usia kritis dalam dorongan berprestasi. Dorongan berprestasi membentuk kebiasaan pada anak untuk mencapai sukses ini cenderung menetap hingga dewasa. Apabila anak mengembangkan kebiasaan untuk belajar atau bekerja sesuai, di bawah, atau di atas kemampuannya, maka kebiasaan ini akan menetap dan cenderung mengenai semua bidang kehidupan anak, baik dalam bidang akademik maupun bidang lainnya. Psikolog perkembangan anak memberi sebutan anak pada masa ini sebagai usia berkelompok. Pada usia ini perhatian utama anak tertuju pada keinginan diterima oleh teman-teman sebaya sebagai anggota kelompoknya. Oleh karena itu, anak ingin dan berusaha menyesuaikan diri dengan standar yang disepakati dan berlaku dalam kelompok sehingga masa anak ini disebut juga usia penyesuaian diri. Anak berusaha menyesuaikan diri dengan standar yang berlaku dalam kelompok,misalnya dalam berbicara, penampilan dan berpakaian, dan berperilaku.

Periode ini juga disebut usia kreatif sebagai kelanjutan dan penyempurnaan perilaku kreatif yang mulai terbentuk pada masa anak awal. Kecenderungan kreatif ini perlu mendapat bimbingan dan dukungan dari guru maupun orang tua sehingga bekembang menjadi tindakan kreatif yang positif dan orisinal, tidak negatif dan sekedar meniru tindakan kreatif orang atau anak yang lain. Selain itu, periode ini disebut juga dengan usia bermain, karena minat dan kegiatan bermain anak semakin meluas dengan lingkungan yang lebih bervariasi. Mereka bermain tidak lagi hanya di lingkungan keluarga dan teman di 
sekitar rumah saja, tapi meluas dengan lingkungan dan teman-teman di sekolah.

Anak Usia 6-12 tahun adalah masa usia sekolah tingkat SD bagi anak yang normal. Perkembangan anak masih sangat dipengaruhi oleh lingkungan keluarga. Sebagai orang tua harus mengetahui pertumbuhan dan perkembangan anaknya terutama pada usia ini karena pertumbuhan anak-anak sangat pesat yang harus diimbangi dengan pemberian nutrisi dan gizi yang seimbang.

Faktor-faktor yang mempengaruhi tumbuh kembang anak :

\section{Berdasarkan faktor genetik}

- Faktor keturunan - masa konsepsi

- Bersifat tetap atau tidak berubah sepanjang kehidupan

- Menentukan beberapa karakteristik seperti jenis kelamin, ras, rambut, warna mata, pertumbuhan fisik, sikap tubuh dan beberapa keunikan psikologis seperti temperamen

- Potensi genetik yang bermutu hendaknya dapat berinteraksi dengan lingkungan secara positif sehingga diperoleh hasil akhir yang optimal.

\section{Berdasarkan faktor eksternal / lingkungan}

Mempengaruhi individu setiap hari mulai konsepsi sampai akhir hayatnya, dan sangat menentukan tercapai atau tidaknya potensi bawaan. Faktor eksternal yang cukup baik akan memungkinkan tercapainya potensi bawaan, sedangkan yang kurang baik akan menghambatnya.

Ciri-ciri anak usia 6-12 tahun menurut gunarsa (1990:60) adalah :

a) Label yang digunakan oleh orang tua. Bagi sebagian besar orang tua, usia 6-12 tahun merupakan usia yang menyulitkan, merupakan suatu masa dimana anakanak tidak mau menuruti perintah orang tua dan lebih banyak dipengaruhi oleh teman-teman sebayanya daripada oleh orang tua dan anggota keluarga yang lain.

b) Label yang digunakan oleh para pendidik. Bagi para pendidik anak usia 6-12 tahun merupakan usia sekolah dasar. Pada usia tersebut anak-anak diharapkan memperoleh dasar-dasar pengetahuan yang dianggap penting untuk keberhasilan penyesuaian diri pada kehidupan dewasa, dan mempelajari berbagai keterampilan penting tertentu, baik keterampilan kurikuler maupun ekstrakurikuler. Para pendidik juga memandang periode ini sebagai periode yang mengkhawatirkan dalam dorongan berprestasi, suatu masa dimana anak membentuk kebiasaan untuk mencapai sukses, tidak sukses, atau sangat sukses. Sekali terbentuk kebiasaan untuk bekerja dibawah, diatas atau sesuai dengan kemampuan cenderung menetap sampai dewasa. Karena tingkat perilaku berprestasi yang tinggi pada masa anak-anak mempunyai korelasi/pengaruh yang tinggi dengan perilaku berprestasi pada masa dewasa.

Tugas perkembangan anak umur 6-12 tahun menurut Gunarsa adalah :

a) Belajar melatih kemampuan fisik yang diperlukan agar dapat melaksanakan permainan atau olahraga yang biasa.

b) Membentuk sikap-sikap tertentu terhadap dirinya sebagai pribadi yang sedang tumbuh dan berkembang.

c) Belajar bergaul dengan teman-teman seumurnya.

d) Mengembangkan kemampuan dasar dalam membaca, menulis dan menghitung.

e) Mengembangkan nurani, moralitas dan skala nilai.

f) Memperoleh kebebasan pribadi.

g) Membentuk sikap terhadap kelompok sosial dan institusi. 
Televisi merupakan sistem elektronik yang mengirimkan gambar diam dan gambar hidup bersama suara melalui kabel atau ruang. Sistem ini menggunakan peralatan yang mengubah cahaya dan suara ke dalam gelombang elektronik dan mengkonversinya kembali ke dalam cahaya yang dapat dilihat dan suaranya dapat didengar.(Soerjokanto 2003:24). Dalam melakukan penyiaran televisi memiliki peraturan yang telah dikeluarkan oleh Komisi Penyiaran Indonesia. Peraturanperaturan ini haruslah dipenuhi oleh pihak televisi apabila tidak KPI dapat memberikan sanksi bahkan memberhentikan suatu tayangan. Selain itu KPI juga mengeluarkan klasifikasi penyiaran televisi yang berguna bagi penonton untuk dijadikan pedoman dalam menonton televisi. Klasifikasinya adalah sebagai berikut :

- Klasifikasi R (Remaja 13-17 tahun), Siaran untuk remaja yakni yang berumur 13-17 tahun

- Klasifikasi P (Pra 2-6 tahun), Siaran untuk anak-anak Pra Sekolah yaitu yang berusia 2-6 tahun.

- Klasifikasi A (Anak 7-12 tahun), Siaran untuk anak-anak yakni khalayak dengan usia 7-12 tahun.

- Klasifikasi SU (Semua umur 2+ tahun), Siaran untuk semua umur yakni khalayak diatas umur dua tahun.

- Klasifikasi D (Dewasa 18+ tahun), Siaran untuk dewasa yakni khalayak dengan usia diatas 18 tahun.

Maksud diadakannya kajian ini adalah untuk mengetahui seberapa besar pengaruh peranan orang tua terhadap perilaku anak. Dalam penelitian ini peneliti akan memfokuskan kepada pengaruh bimbingan orang tua terhadap anak yang menjadi pemirsa televisi. Selain itu penelitian ini akan melihat pula perbedaan antara anak dengan dan tanpa bimbingan orang tua dalam menonton televisi.

Dalam penelitian ini peneliti akan memfokuskan pada anak usia 6-12 tahun. Pada usia ini anak akan mengalami tahap sebelum puber. Pada tahap ini pula anak akan lebih luas mengenali lingkungan sekitanya. Tidak mendengarkan nasihat orang tua juga kemungkinan besar terjadi pada tahap anak usia ini. Apabila anak pada tahap usia 6-12 tahun dibiarkan menonton televisi dengan tayangan-tayangan negatif dikhawatirkan akan berakibat fatal kepada perkembangan psikologisnya. Oleh karena itu peranan orang tua menjadi sangat penting. Orang tua harus dapat mengawasi anaknya dalam menonton televisi.

Peneliti mengharapkan hasil dari penelitian ini dapat berguna baik secara akademis maupun secara praktis. Hasil dari penelitian ini dilihat secara akademis adalah diharapkan penelitian ini dapat berguna untuk memberikan sumbangan kepada jurusan ilmu kesejahteraan sosial, khususnya berkaitan dengan peranan orang tua dirumah terhadap anak. Selain itu memberikan gambaran kepada pekerja sosial untuk mengetahui bagaimana memberikan treatment yang tepat bagi orang tua yang memiliki kewajiban memberikan bimbingan serta pengarahan bagi anaknya terutama dalam menonton televisi. Selain itu secara praktis penilitian ini diharapkan dapat dijadikan pegangan bagi orang tua untuk memberikan perhatian serta peranan yang dibutuhkan anak.

\section{SIMPULAN}

Anak usia 6-12 tahun telah banyak menerima dampak negatif dari televisi dengan berubahnya perilaku mereka sebelum dan setelah menonton. Ayah dan ibu harus memberikan tanggung jawab penuh terhadap perannya sebagai orang tua. Sedangkan pihak stasiun televisi seakan tidak memperdulikan kekerasan visual yang setiap hari mereka sajikan untuk anak-anak. Kekerasan visual yang terus menerus dipertontonkan kepada anak akan terekam di otak anak dan anak akan terdorong untuk meniru perilaku yang mereka lihat di televisi.sebagai hiburan keluarga tentu tayangan-tayangan negatif seperti ini dapat menyebabkan dampak yang tidak sehat untuk 
kejiwaan anak. Dalam penelitian ini peneliti akan memfokuskan pada anak usia 6-12 tahun. Pada usia ini anak akan mengalami tahap sebelum puber. Pada tahap ini pula anak akan lebih luas mengenali lingkungan sekitanya. Tidak mendengarkan nasihat orang tua juga kemungkinan besar terjadi pada tahap anak usia ini. Apabila anak pada tahap usia 6-12 tahun dibiarkan menonton televisi dengan tayangan-tayangan negatif dikhawatirkan akan berakibat fatal kepada perkembangan psikologisnya. Oleh karena itu peranan orang tua menjadi sangat penting. Orang tua harus dapat mengawasi anaknya dalam menonton televisi.

\section{REKOMENDASI}

Rekomendasi dari peneliti terhadap penelitian ini adalah:

- Orang tua harus melakukan pengawasan penuh terhadap anak dalam menononton televisi.

- Meningkatkan kepedulian orang tua terhadap perilaku anak yang dapt berubah karena menonton televisi.

- Memberikan sarana hiburan lain untuk anak yang dirasa lebih memberikan nilai edukatif selain menghibur.

\section{DAFTAR PUSTAKA}

Sugiyono.2014.METODE PENELITIAN

KUANTITATIF, KUALITATIF

DAN R\&D.Bandung.Penerbit ALFABETA

http.kompasiana.com-generasi-yang-hilangbunuh-diri-oleh-anak.html

http://www.kpi.go.id/

Thamrin Nasution dan Nurhalijah Nasution, Peran Orang Tua dalam

Meningkatkan Prestasi Belajar Anak, Jakarta: BPK Agung Mulia,

1989.

http://pondokibu.com/pertumbuhan-danperkembangan-anak-usia-6-12tahun.html

http://warnawarnianak.blogspot.com/2011/03/karakteri stik-perkembangan-masa-anak.html

http://unsilster.com/2012/04/pengertiankeluarga-dan-fungsi-keluarga/ 